\title{
The Impact of Digital Transformation on the World of Work and on Human Resource Management \\ DOI 10.17047/Hadtud.2020.30.E.146
}

\begin{abstract}
:
I analysed labour market movements in my presentation at the HSZOSZ conference held in Debrecen in November 2019. I found that the flexible and quick response to the challenges of the speedily changing environment has always been a demanding task for organizations. In this day and age, technological development, innovative aspirations, robotization and digitalization have an impact on the functions and mindset of HR management. Creating knowledge-based society, the explosive development of technology and the upsurge of robotics can reshape the needs of labour market. On the other hand, this is all closely related to lifelong learning, the expansion of knowledge production, knowledge maintenance, knowledge management, and knowledge transfer. Talent management, along with catching up, have now become principal elements of value-added work.
\end{abstract}

Keywords:

challenge, resource, digital transformation, talent, knowledge worker's job

\section{A digitális transzformáció hatása a humánerőforrás menedzsmentre és tágabb értelemben a munka világára napjainkban}

\begin{abstract}
Absztrakt:
A tanulmány a 2019 novemberében, Debrecenben, a HSZOSZ konferencián tartott előadás szerkesztett változata. Elemeztem a munkaerő piaci mozgásokat, és megállapítottam, hogy a munkaszervezetek számára mindig is kihívást jelentő feladat volt a változó környezeti kihívásokra való rugalmas és gyors reagálás. Napjainkban a technológia fejlődése, az innovációs törekvések, a robotizáció és a digitalizáció, a humánerőforrás-gazdálkodás szemléletére, funkcióira is hatást gyakorolnak. A tudásalapú társadalom megteremtése, a technika, a technológia, a robotika robbanásszerü fejlődése átrajzolhatják a munkaerőpiac igényeit. Mindez - másfelől - szorosan összefügg az élethosszig tartó tanulással, a tudás-elöállítás bővítésével, a tudáskarbantartással, a tudásmenedzseléssel, a tudástranszferrel. A tehetséggondozás a felzárkóztatással együtt napjainkra a hozzáadott érték alapú munkavégzés meghatározó elemévé vált.
\end{abstract}

Kulcsszavak:

Kihívás, erőforrás, digitális transzformáció, tehetség, tudásmunkás

\footnotetext{
1 Magyar Hadtudományi Társaság - Hungarian

Association of Military Science;
} hadtudomany@gmail.com; ORCID: 0000-0002-3294-6306 
Flexible and quick response to the challenges of the speedily changing environment has always been a demanding task for organizations. In this day and age, technological development, innovative aspirations, robotization and digitalization have an impact on the functions and mindset of HR management. Let me - as secretary general of civil-professional organization National Association of Human Professionals (HSZOSZ) - quote from our mission statement on the intended responses to these challenges: "We consider the ceaseless improvement of Hungarian HR profession our mission. To this end, we support all endeavours that can make the use of human resources more efficient and more humane. We organize professional conferences and symposia. We intend to play an important role in scientific HR research projects, and in the elaboration and publication of scientific results and their dissemination to a wide publicity. Thus, we provide opportunities to develop good professional practices and to improve the quality, efficiency, and effectiveness of HR management. Via the development of HR management practices and the sharing of such knowledge and experiences, we can indirectly contribute to the development of economy. Key pillars of our value system: expertise, commitment to lifelong learning and building a knowledge-based society, social sensitivity, and high-level professional ethics". I based my present article on the final research report created by the National Association of Human Professionals and Milton Friedman University - published January 1, 2018. ${ }^{2}$

"The development of technology, innovative procedures and globalization processes have influenced the approach and functions of human resource management." We live in a rapidly changing age on the verge of a digital "big bang", and this is especially true of the world of work. In this age, Human Resource Management (HRM) paradigms are and will be sent to oblivion. Both employers and employees must recognize these changes and react to them. Employers should incorporate e.g. by "digital transformation” - into their resource-based HRM activities and into their labour administration, too all opportunities and methods which can contribute to the quality of work, to effective operation, and offer modern responses to the challenges of the future. Globalization, robotization, and digitalization can redraw Hungarian employment policies, change the content, classification, knowledge, and competency sets of jobs, professions, and groups of professions. This may happen sooner than we would think.

\footnotetext{
2 Poór József - Schottner Krisztina: Változások a humánerőforrás menedzsmentben a digitális transzformáció útján. Kutatási zárójelentés. Budapest, Milton Friedman Egyetem, 2018. november 1. (Changes in Human Resources Management through digital transformation. Final Report on Research, 2018.) http://www.hszosz.hu/members/index.php/tudastar/kutatasi-jelentesek (Accessed: 04 February 2020)

${ }^{3}$ Dajnoki Krisztina - Héder Mária: „Új szelek fújnak” - a HR válasza a globalizáció és a változás kihívásaira. („New Winds Blow” - The Answer of HR for the Challenges of Globalization and the Change.) Hadtudomány, 2017. évi elektronikus lapszám, p 91.
} 


\section{Changes in Human Resource Management through Digital Transformation}

The final research report is available at Poór - Schottner (2018). The summary of the research report's introductory part - completed in the autumn of 2018 - states that the most urgent task for Hungarian organizations - in order to improve the performance of national economy - is to "build a culture of continuous learning, adaptation, growth and personal development". I fully agree with this statement. "In addition, they must enhance employee commitment and productivity by shaping employee experience". Reading between the lines, we can also sense a further message from the authors: "Knowledge management should be part of education and employment policies in tandem with talent management, catching-up, creating equal opportunities, employing low-skilled workforce." The empirical data of the study show that HRM is in constant motion, as is the world of work itself. These elements are of course, chiefly organization-specific, as they are highly dependent on "success factors, competitive advantages", managerial mentality, and value systems embedded in the culture of each organization. Nowadays, employee engagement often mentioned in relation with retention - can improve thanks to the value-creating activity of HRM, especially in the case of identified "key people". The researchers also studied the concept of "digital transformation". By using the approach of advisory firm i-SCOOP (2016), they formed their own definition of digital transformation: "a profound transformation of business and organizational activities, processes, competencies and models via digital technologies, making the most of the changes and opportunities arising from their accelerating social impact, by strategies and priorities, by changing the present and future ways of thinking". ${ }^{4}$ One of the most important, if not the most important, preparatory tasks of every research project is to gather, systematize, and create its theoretical foundations. Having studied the results of the study, I daresay that the re-interpretation of labour market processes and existing theoretical foundations is needful. Earlier clichés are no longer serviceable, because they cannot provide an adequate solution in the renewal of HRM. Therefore, we must seek a new consensus relying on new foundations. It is to be built on mutual trust and collaboration among government actors, employers, employees, HRM systems, and civil society organizations. A quote from the study: "to succeed in the digital transformation of HRM and the deployment of e-HRM, raising awareness and acceptance among employees and other stakeholders regarding these changes are essential. Furthermore, it is also imperative to align the new processes of e-HRM with

\footnotetext{
4 i-SCOOP. (2016): Digital transformation: online guide to digital business transformation. from iSCOOP: https://www.i-scoop.eu/digital-transformation/ (Accessed: 04 February 2020) See also: Poór József - Schottner Krisztina - Frajna Piller Annamária - Hárskúti János - Kis-Kálmán Dániel: Változások az emberi erőforrás menedzsmentben a digitális transzformáció útján egy magyarországi empirikus kutatás tükrében. Munkaügyi Szemle, 62 (2019/2). pp. 8-14. http://real.mtak.hu/93367/1/Poor et al 20192 Munkaugyi Szemle.pdf (Accessed: 04 February 2020)
} 
those of existing systems. Employees need to be taught how to handle their HRM issues in new ways, how to use fresh IT tools and applications." In my opinion, the process of digital learning should be started in public education and extended at secondary schools and in higher education. Nowadays a self-sufficient citizen and employee is supposed to hold proper digital knowledge in order to organize finances, personal documents, tax returns, seeking a job and so on. It is our shared responsibility to make all this an integral part of organizational culture. Reliability, trust, data protection (GDPR), fast, accurate data management, adequate access to data, quick orientation can be a guarantee and a basis for digital collaboration with employees. The researchers also identified the most IT-intensive areas of HRM in Hungary today. The results: "More than $80 \%$ of respondents utilize IT in employee selection and payroll accounting. This makes these two areas the most frequent users of information technology. Interestingly, the next area in line is training and development, while the rate IT usage is only $60 \%$ in recruitment. More than half of the participants perform digital HR analysis and data capture. The same is true for the administration of benefits". ${ }^{5}$

Having analysed labour market movements, Professor József Poór - in his presentation at the HSZOSZ conference held in Debrecen in September 2017 - drew the attention to the fact that nearly 7 million people (mainly skilled employees) have recently left Central and Eastern Europe so far. In this context, I would like to pinpoint the conclusion of the IBM-GKI Conference 2007, stating that Hungarian workers are immobile and this is, among other things, due to the market handicap caused by their low level of education. I also point out the fact, that while for example in Sweden, the employment rate of the low-skilled is $70 \%$, it is hardly $30 \%$ in Hungary. Are the unqualified real power reserves or much rather losers of the competition forced by globalization? In the latter scenario, the question we must answer is how their catching up can be solved by training. I believe that only measures taken at government level can overcome this issue. Scientists shall resort to their own tools: they can actively support government efforts by conducting relevant research projects, like the one mentioned here. In the Lectori Salutem section of the book "The World of Work at the Beginning of the 21st Century" Prof. Dr. Miklós Dobák made the following statement: "Knowledge-based society, knowledge-based economy and lifelong learning are all concepts that simultaneously define the labour market's processes of our century and employment policy responses to them." ${ }^{\prime 6}$ Having observed the problem from the employees' side, we can conclude that the dynamics

\footnotetext{
5 Poór József - Schottner Krisztina: Változások a humánerőforrás menedzsmentben a digitális transzformáció útján. Kutatási zárójelentés, 2018. (Changes in Human Resources Management through digital transformation. Final Report on Research, 2018.)

${ }^{6}$ Sebök Marianna (szerk.): A munka világa a 21. század elején. (The World of Work at the Beginning of the 21st Century.) Budapest, Saxo Kiadó, 2018. p. 13.
} 
and the needs of individual development are influenced by a plethora of factors. Creating knowledge-based society, the explosive development of technology, and the upsurge of robotics can reshape the needs of labour market. On the other hand, all this is closely related to lifelong learning, the expansion of knowledge production, knowledge maintenance, knowledge management, and knowledge transfer. Talent management, along with catching up, have now become principal elements of valueadded work.

In the race induced by the globalized world, employees should be more diverse, more self-sufficient, and better qualified than ever before. Scientists must navigate them - regardless of their age - in this. We should all develop the ability to "price" our knowledge (as labour market always does so), our acquired professional experience, our "tacit knowledge" (visible knowledge, a combination of theoretical and experiential knowledge), in the domestic and in the international labour market. Career models can provide similar aid: we need to explain the benefits of a career system to a wide range of employees. Flexible adaptation can be achieved by gradually shifting the focus of labour thinking to jobs. This can serve as a point of reference for employees. Creating job-based systems, resource- and job-based HRM would promote employee mobility. Thus, facilitate switching among career paths and multi-directional careers, from the public sector to the competitive sector - and vice versa. As far as carrier advancement is concerned, we can now talk about even a "project career", but we also need to notice "career pressure" that shocks young employees today at an early stage in their career. An effective tool is job analysis, by which jobs can be classified based on carrier paths, job identification codes can be created (not at all identical to official job classification codes used for state statistical purposes) and used for ranking jobs. This way, we can assess the labour market value and prestige of each class of jobs and each job. As I see, job descriptions should include job tasks and competencies (knowledge, experience, skills, abilities, personality traits, behavioural and social competencies, digital skills, etc.). Furthermore, the codes should also embrace job performance requirements based on organizational knowledge maps as well as training needs demanded by the job. At the same time, today's "knowledge worker's job" already presupposes the existence of a "job competency register" and "competency-based performance evaluation".

With regard to employment rate, we are compelled to see that facts are stubborn and quite controversial. The "aging" Europe, the decline in Hungarian birth rates, or the migration of low- skilled Hungarian workers into richer EU Member States, are the result of the combined effect of unemployment and labour shortages and their contradictions. Globalization that characterizes the first decades of the 21st century is a challenge for every region and each country within. The recognition, conscious analysis of the problem and the search for adequate responses have only a few decades of history. In the first half, in America, Professor Warraenstein had predicted the consequences of global processes we undergo at present. He foresaw its positive 
and negative impacts on national economies and national labour markets. While material resources for expanding production are limited and some are already depleting, there are opportunities in the dynamization of human resources worldwide. As part of the responses to globalization, the most advanced countries experienced a full vertical expansion of training about 60-70 years ago. The focus of the government's educational, employment, and social policy efforts is to meet the needs of the labour market, to make social groups that are prone to retreat catch up, and to promote social cohesion. Professor David C. Korten (who is also the founder and chairman of the "Human-centric Development Forum") in one of his books calls the business policy and capital investment of profit-maximizing capitalist companies "vulture capital" - due to their tendency to prey on and destroy host economic culture and ecological balance. Their objective is not merely normal but much rather extra profit (preferably "luxury" profit), and unremitting growth, even though the reserves of sustainable development are now exhausted. The hardships of recent crises wake us up to the aftermaths. As Professor Korten put it: "In an economy that measures performance by the amount of money generated, and sees people as the main source of inefficiency... the economy takes revenge on them... If financial institutions dominate the world, it might be inescapable that the interests of the world of money are placed above the interests of people". The side-effects of the past multi-stage industrial revolution lead us to the following conclusion: "The success of the legendary Henry Ford car factory was also enhanced by its support to employees purchasing self-manufactured automobiles. Hereby, it generated an additional demand to buy, which was a so-called comparative advantage (and a win-win situation) for both sides." The present crisis hit the very foundations of competitive market economy, which had rested on reciprocity and mutual trust. The principle of trust has been torpedoed on the financial market, the real estate market, and the markets of other goods. Gyula Lakatos in his presentation on the economic appreciation of human capital in 2003, stated: "Major companies have devised the concept of knowledge management with the aim of meeting the knowledge needs of effective business operation and identifying the existing and acquired knowledge capital ready for use. A part of this is the trading of knowledge - knowledge exchange - that takes place on the knowledge market, where knowledge is sold and purchased". 8

\footnotetext{
7 David C. Korten: World domination of capital companies. When Corporations Rule the World (1995). In Hungarian A tőkés társaságok világuralma. Budapest, Kapu Alapítvány,1996.

8 Lakatos Gyula. Az emberi erőforrás gazdálkodás változása a humántőke gazdasági felértékelődésével. Előadás a 2003. október 13-14-én, Sopronban tartott humánpolitikai szimpóziumon. (Economic appreciation of human capital. At the Human Policy. Symposium in Sopron (13-14 October 2003).
} 
The constant presence and intensity of change in the world of work and its impacts on competencies and training led scientists - as early as in the mid-1990s - to seek a solution to this issue as well Bratton and Gold" "introduced the concept of hard (hard) and soft (soft) competencies in their study. From their view, those organizations that emphasize the importance of hard competencies and regard employees no more than one of the organization's many resources, represent strategic management approaches that are founded on predictability, measurability, and rationality. Soft competencies are, on another note, considered to be the individual's specificities. The focus of innovative thinking, motivation, commitment, and communication is on a management mindset that esteems human resources as a source of competitive advantage. A resource to be motivated and prized by appropriate training and rewards". In my opinion, it is necessary to mention here professional skills and related experiential knowledge - as parts of hard competencies - that is, "tacit knowledge" itself. As for "soft competencies", they should be thought of as "success factors that can be developed by knowledge generation". At the same time, we need to know that individual intelligence quotients that have been tested so zealously cannot be boosted, since they are largely inherited. In knowledge of the challenges of today and of the near future, competencies - including digital literacy - are, significantly appreciated, either in terms of digital recruitment, selection or in respect of job descriptions and competency-based performance evaluation as mentioned above. In Hungary, the "educational lobby", organisations in the areas of education and training have now recognized all this. Let us think about the National Core Curriculum (basic competencies), colleges, universities, as well as the training requirements for adult education and the competency sets to be developed by the subjects taught there. Our task is clear. The analysis of the empirical data sends the same message to us as well as to HRM, which is ready for and capable of renewal: it is time for us to act.

9 Bratton, J. and Gold, J.: Human Resource Management Theory and Practice. London, Macmillan,1994. 


\section{REFERENCES}

Bratton, J. and Gold, J.: Human Resource Management Theory and Practice. London, Macmillan,1994.

Dajnoki Krisztina - Héder Mária: „Új szelek fújnak” - a HR válasza a globalizáció és a változás kihívásaira („New Winds Blow” - The Answer of HR for the Challenges of Globalization and the Change). Hadtudomány, 2017. évi elektronikus lapszám, pp. 84-93.

Korten, David C.: World domination of capital companies. When Corporations Rule the World (1995). In Hungarian A tőkés társaságok világuralma. Budapest, Kapu Alapítvány, 1996.

Lakatos Gyula: Az emberi erőforrás gazdálkodás változása a humántőke gazdasági felértékelődésével. Előadás a 2003. október 13-14-én, Sopronban tartott humánpolitikai szimpóziumon. (Economic appreciation of human capital. At the Human Policy. Symposium in Sopron (13-14 October 2003)

i-SCOOP. (2016): Digital transformation: online guide to digital business transformation. from i-SCOOP: https://www.i-scoop.eu/digital-transformation/

Pató Gáborné Szűcs Beáta: The 3D Job Description, Jour-nal of Management Development, Vol. 34 (2015) Iss: 4, pp. 406-420.

Pató Gáborné Szűcs Beáta: Formal Options for Job Descriptions - theory meets practice, Journal of Management Development, Vol. 36. (2017) Iss. 8, pp. 10081028., https://doi.org/10.1108/JMD-01-2016-0019

Sebők Marianna: A munka világa a 21. század elején (The World of Work at the Beginning of the 21st Century). Budapest, Saxum Kiadó, 2018.

Poór József - Schottner Krisztina: Változások a humánerőforrás menedzsmentben a digitális transzformáció útján. Kutatási zárójelentés. Budapest, Milton Friedman Egyetem, 2018. november 1. (Changes in Human Resources Management through digital transformation. Final Report on Research, 2018.) http://www.hszosz.hu/members/index.php/tudastar/kutatasi-jelentesek

Poór József - Schottner Krisztina - Frajna Piller Annamária - Hárskúti János - KisKálmán Dániel: változások az emberi erőforrás menedzsmentben a digitális transzformáció útján egy magyarországi empirikus kutatás tükrében. Munkaügyi Szemle, 62 (2019/2). pp. 8-14. http://real.mtak.hu/93367/1/Poor et al 20192 Munkaugyi Szemle.pdf 